\title{
Per Aspera ad Pax
}

The Syrian Crisis: A Thorny Path from War to Peace Alexander G. Aksenyonok

The second decade of the 21st century began with a string of explosive protests in the Middle East and North Africa. The region has become a source of violence and terrorism, dramatic national upheavals, humanitarian catastrophes, and waves of migration. Most countries (Egypt, Tunisia, Morocco, Jordan, Saudi Arabia) have launched the needed socioeconomic reforms, albeit belatedly, but outcomes are difficult to predict. A way out of the profound systemic crisis is yet to be found.

\section{WHAT MAKES THIS CONFLICT SO DISTINCT}

The Syrian crisis, while reflecting the general grievous state of the Greater Middle East, is still a special case resulting from profound changes in the alignment of forces at the global and regional level. The majority of the 21 st century's geopolitical, ideological, social, and ethno-religious cataclysms have been concentrated in precisely this region.

The conflict in Syria unfolded in a historical period when Russia-U.S. relations were slowly, but surely, deteriorating from the erstwhile partnership of the late 1990s and early 2000s to a Cold War confrontational model. The generally accepted norms of international law were unilaterally revised, while a collective crisis settlement mechanism advocated by Russia never materialized. As the President

Alexander G. Aksenyonok, Ambassador Extraordinary and Plenipotentiary, Vice-President of the Russian International Affairs Council.

This article is an abridged version of the paper written for the International Valdai Discussion Club. The original version is available at: http://valdaiclub.com/a/valdai-papers/the-syriancrisis-a-thorny-path-from-war-to-peace/ 
of Russia suggested at the Valdai Forum in 2014, this mechanism might include a "coherent system of reciprocal commitments and agreements" and "clear-cut conditions under which interference is necessary and legitimate" (Valdai, 2014).

The protracted Syrian crisis has presented the international community with a major dilemma: Will it be able to extinguish the tinderbox of conflicts or will it allow regional centers of power to engage in military rivalries designed to promote their geopolitical interests and indulge their outsize ambitions. In this sense, the outcome of the civil war in Syria will have implications that go far beyond the regional framework. When the nationalist wave was at its crest, Egypt was called the "head of Arabism and Syria, its "heart'." The concept of Arabism no longer has the same ring to it: Egypt is no longer the leader, new centers of financial and political influence have emerged in the Gulf area, and non-Arab regional players such as Turkey, Iran, and Israel are now ascendant. The altered alignment of forces at the regional level has turned Syria into an arena where Sunni Saudi Arabia and Shiite Iran, the two religious centers and leaders of the two main Islamic denominations, are locked in an indirect battle (The Iranian-Saudi Hegemonic Rivalry, 2017). A full-scale civil war in the centre of the Arab world with its closely intertwined interests-both clashing and to some extent overlapping-has complicated the search for mutually acceptable agreements and made coalition ties fluid and ambiguous.

In Syria, the military contingents and bases of six foreign statesRussia, Iran, Turkey, the U.S., France, and the UK-are deployed in close proximity. But it is only Russia and Iran that have international legal grounds (an invitation from the Syrian government) for being there. This incredibly compact foreign military presence, including non-government paramilitary units (proxies), not only involves unpredictable risks but also equips each of the players on the ground with military and political tools that make it possible to disrupt any final outcome it finds unacceptable. The Syrian crisis is also a mirror reflecting the growing influence of regional actors, each playing a game of its own within the wider context, whose local agendas increasingly often clash with the global interests of the major powers.

There is yet another reason why the Syrian crisis is so idiosyncratic and difficult to settle. The multilateral talks on the future system 
of government in Syria have been held against the background of continued military operations punctured by short-lived ceasefire. In the international context, institutional reforms normally follow the military phase. In Syria, internationally mediated agreements on reforms between the direct participants in the conflict should in effect become the condition for ending the hostilities and focusing joint efforts on combating the persisting terrorist threat.

\section{THE CURRENT STATE OF PLAY ON THE MILITARY MAP}

The eight-year Syrian crisis can be roughly divided into two stages: 1) before Russia's decisive military intervention in September 2015, and 2) after the Russian Aerospace Forces launched operations in Syria, enabling Damascus to restore control over the majority of Syrian territory and to destroy the military infrastructure of ISIS (banned in Russial and other terrorist groups.

The sporadic anti-government protests in late February and early March 2011 were initially peaceful in nature. The protests reached critical mass and began sweeping the country after the Syrian leadership abruptly had given in to the omnipotent securicrats who urged the president to stop making concessions and put down the uprising by force. In April and May, heavy weapons were used against peaceful protesters. Legislative measures to partially liberalize the political regime, calls to start a national dialogue, and even the approval of a new constitution in February 2012 were already unable to diffuse the tensions.

The Syrian opposition, as represented by political emigres and underground civil society organizations with motley ideological beliefs (ranging from liberals to Trotskyites to radical Islamists), was not in itself a threat to the regime, which relied on a well-oiled mechanism of harsh authoritarian power. The rapid (in fact, instantaneous) transition to the military phase was caused by the overwhelming synergy between the explosion of spontaneous protests aided by the wide use of modern communications technologies, the authorities' disproportionate military response, and desertions from the army in combination with the mass infiltration of militants and arms across the borders from neighboring countries, which was directly supported by Turkey with financial backing from Arab Gulf monarchies, primarily Saudi Arabia and Qatar. Moreover, leaders in Syria's regional environs 
had "old scores" to settle with al-Assad: relations with the Syrian president in the run-up to the crisis varied from close cooperation to mutual recrimination. Religious factors were initially of minor importance, but as hostilities expanded and new players got involved, all sides began using religion as a means of mobilization.

The U.S. and leading EU countries immediately declared the alAssad regime illegitimate, recognized the opposition's political wing as the legitimate representative of the Syrian people, and pressured Damascus via the UN and other international organizations. The League of Arab States (LAS) took the unprecedented step of suspending Syria's membership. At that moment, regime change along the lines of Libya was a unifying principle for the anti-Assad coalition that emerged in the region. But as time went on, the clash of interests between the U.S. and its regional partners as well as among the major regional players (Turkey, Saudi Arabia, the UAE, and Qatar) reconfigured coalition ties and opened up new dimensions in the Syrian crisis.

However, the initial knee-jerk reaction was a major political blunder, as leading Western experts now admit. The United States failed to establish a firm base of military-political support in the Arab armed opposition. Nor did it manage to differentiate "moderate Islamists" from the rapidly proliferating terrorist organizations. But the insistent demands that al-Assad must go only fed the opposition's illusions that they could win a military victory and fueled the competition for political influence and control over arms flows and outside funding within their ranks. America's unconditional support for the opposition movement, where jihadists with links to ISIS and Al-Qaeda (banned in Russia) were rapidly gaining strength, predetermined the weakness of the U.S. diplomatic efforts and constrained the room for manoeuvre. This made Washington hostage to émigré politicians with their exorbitant demands and to their regional sponsors. It reached the point where U.S. policy was all too clearly playing into the hands of terrorists. This became particularly clear in the summer of 2014, when ISIS achieved spectacular military successes in Iraq and Syria, putting the Barack Obama administration in an even more awkward position.

Between 2012 and 2015, Damascus was burning through internal resources to neutralize military pressure at home. The armed 
opposition was expanding its zones of territorial control not only in northern and eastern Syria, where radical Islamists spilled over from Iraq, but also in the country's densely populated central areas. The Syrian army was not ready for urban warfare and gradually found itself on the defensive, focusing on guarding distant approaches to the capital, strategic centers, and transport infrastructure.

Lebanon-based Hezbollah joined the hostilities in 2012 while Iran was expanding direct military aid to Syria, including the enlistment of Shiite militias from Iraq, Afghanistan, and Pakistan. This made it possible to halt enemy advances towards vital centers for some time but also aggravated relations between different ethnic and religious communities, making the conflict particularly fierce on both sides. Having established close relations with Syria back in the mid-1980s, Iran managed to gain a firm foothold in Iraq and Lebanon during the years of regional upheaval and create extensive military infrastructure under its control. The Iranians regard Syrian territory as a key component of their national security strategy, which is focused on pushing back against Saudi Arabia and its claims to leadership in the Islamic world. Since the Donald Trump administration unilaterally withdrew from the Joint Comprehensive Plan of Action (JCPOA) and ratcheted up economic and political pressure against Tehran, Iran's regional strategy has been put to the test like never before. Signs of internal disaffection are surfacing more and more often in response to the dramatic financial constraints, growing economic hardship, and loss of life in the Syrian war (Iranians Respond, 2018). Questions are being asked about the limits of Iran's regional security and Syria's place therein as a crucial component of its broader strategy in relations with the U.S. and Saudi Arabia.

Turkey, which opted for rapid regime change in Damascus and support for Islamist organizations with ideological proximity to Recep Erdogan's ruling party, has modified its position substantially in the course of the conflict. This change of emphasis in regional policy was brought about by complications in the transition from a parliamentary republic to a strong presidential regime as well as by disappointment with U.S. and EU policy in Syria, on the one hand, and an understanding of the advantages of working with Russia on Syria as part of a broader bilateral cooperation framework, on the other. 
The changing regional picture was largely the result of the Kurdish factor, which always played and continues to play a significant role in the domestic politics of the countries forming the so-called Kurdish Triangle (Syria, Turkey, and Iraq). Soon after the start of hostilities, the Syrian government decided to phase out its military presence in north-eastern areas, where the Kurdish majority immediately established control. Erdogan's war on two fronts-one with the alAssad regime and the other with the armed Kurdish groups-failed to yield success and even led to a spate of ISIS terrorist attacks inside Turkey itself. Frictions intensified with the Americans, who had thrown in their lot with the Kurds after the latter had proved highly effective at waging anti-terrorist operations against ISIS. This created a situation where the Syrian Kurds, who got a unique opportunity to merge their enclaves in Afrin and Kobani, thought that this historic juncture was favorable for organizing an autonomous area on the northern border with Turkey (a Western Kurdistan of sorts) with a claim to independence. After Turkey broke off a ceasefire agreement with the Kurdistan Workers' Party (PKK) and banned the Kurdish opposition's legal activities at home, it came to regard the Kurdish self-defense units and their political wing, the Democratic Union Party in Syria, as a terrorist organization on a par with ISIS.

The official rationale for the Turkish armed forces and the Free Syrian Army to launch joint operations in northern Syria was that military intervention would clear the border territory east of the Euphrates of Kurdish forces, create a "buffer security zone" in Syria, and prepare the ground for the return of refugees. By maintaining its partnership with Turkey within the framework of the Astana format, Russia has shown understanding of Turkish concerns based on the Turkish leaders' assurances that they are committed to the territorial integrity of Syria as the end goal of the political process.

Saudi Arabia's role in the Syrian conflict has undergone significant change as well. The tempestuous developments in the region and the expansion of Iranian influence in Iraq, Lebanon, and Bahrain have convinced Riyadh that Iran is planning to encircle the Islamic holy places with a "Shiite belt" and destabilize the Saudi monarchy. Since the start of the conflict, the Saudis have focused on creating a counterweight to Iran in Syria by consolidating ideologically aligned 
local Islamist forces. By means of funding this part of the armed opposition and imposing Saudi influence over structuring its political wing, Riyadh has played a role in escalating the fighting against government forces.

Once the conflict reached its turning point, the balance of gains and losses was not in favor of the military-political groups backed by Saudi Arabia. The policy to undermine the legitimate regime in Syria from within was in open conflict with the protracted military intervention in Yemen, allegedly undertaken in order to restore the same "constitutional legitimacy." The two-front war was becoming increasingly onerous. With ISIS firmly entrenched in Syria and Iraq, terrorist forces in the southern Arabian Peninsula and in Saudi Arabia itself had a free hand to expand their activities. Hopes for a speedy downfall of the al-Assad regime gave way to a more realistic view, something that took place against the background of deteriorating relations with the U.S. Despite the anti-Iran sentiment, they shared, Saudi Arabia was increasingly displeased with the Trump administration's chaotic and unpredictable policy in the Middle East. There were apprehensions that the U.S. was preparing to withdraw from the region. The Saudis were no longer sure that they would have the support they needed at the critical moment, if Iran decided to take advantage of the U.S. pullout and fill the vacuum.

In parallel, Saudi Arabia was promoting relations with Russia, in spite of their differences over Syria, on the basis of broader joint interests in regional and global politics. Regular contacts, including top-level contacts, were working to achieve mutual understanding on fundamental approaches to a Syrian settlement, including the eradication of the terrorist threat, a speedy start to the Constitutional Committee's operations, and assistance to expand humanitarian aid supplies and the return of refugees.

Russia, as acknowledged by all its opponents, has fundamentally altered the trajectory of the Syrian crisis. By the start of its military campaign in Syria, government forces and various loyal militias were fighting on the outskirts of Damascus and had difficulty containing the enemy's advance on the southern front. That a "Green Islamist International" would come to power in the heart of the Arab world seemed like a foregone conclusion. It was at that moment, in the 
summer of 2015, that President al-Assad famously said that it was necessary to "preserve a useful Syria," meaning the Alawite Corridor in the west the country from Daraa in the south along the seacoast to Latakia in the north, that is, about 30-35 percent of Syrian territory.

Since then, a totally different military reality has taken shape. Damascus has regained control over most of its territory laccording to various estimates, between 68 and 70 percent), while the armed opposition is no longer able to conduct active military operations and retains only some of its enclaves in north-western Syria. The "Arab Caliphate" as a quasi-state terrorist entity has been wiped out along with its military infrastructure. At the same time, numerous obstacles, foreseen and unforeseen, will have to be overcome on the path to a post-conflict settlement. Approximately one-third of Syrian territory is controlled by Turkey (the northern enclave stretching from Hatay Province in Turkey to the western bank of the Euphrates) and the "Syrian Democratic Forces" that were specially trained and equipped by the U.S. (northern and north-eastern areas along the Euphrates). Finally, there is still the problem of Idlib in the west, where the deescalation zone covers parts of the Aleppo and Hama provinces. This territory is dominated by jihadist radical Islamists, who have rallied around the Hay'at Tahrir al-Sham terrorist organization lan alliance of Islamist groupings led by Jabhat Fatah al-Sham, formerly-AlNusra Front also banned in Russia).

\section{BETWEEN GENEVA AND ASTANA: PERIPATETIC INTERNATIONAL MEDIATION}

Three UN Secretary General's Special Envoys for Syria have come and gone during the eight years of the conflict, which was internationalized from the start by the Arab states themselves. There were numerous attempts to find a way forward to a settlement through the joint efforts of the international community, none of which led to the desired result, although, it must be admitted, they made an important contribution to the global practice of conflict settlement and yielded considerable knowledge for the purposes of objectively analyzing the causes of failure. International debates have focused on the mediating role of the United Nations putting forward a number of important questions: whether its special envoy can remain impartial, no matter how skilful 
he is as a negotiator, if the UN Security Council members, to whom he reports, support different sides to the conflict, for which reason he is constantly blamed for being partial by this or that side; whether the success of a mediatory mission depends on the mediator's mandate; and finally, whether a "firm mandate" of the kind that was conferred on the EU High Representative for Bosnia and Herzegovina can be more effective in maintaining the needed pressure on the warring sides.

The Arab League launched a mediatory mission during the first few months of armed clashes, but its efforts proved unsuccessful and were quickly discontinued. The regime and the opposition were hoping to gain an early victory with outside support. Besides the Syrian leaders had every reason to distrust the Arab League, which was under the influence of Saudi Arabia and Qatar. In February 2012, the UN stepped in as an international mediator and continues acting in that role. After the UN Security Council had proved incapable of devising coordinated solutions (the West jointly with the Gulf Arab states were pushing for international legitimation of intervention, but all their proposals were resolutely vetoed by Russia and Chinal, the UN General Assembly asked the then Secretary General to appoint his special envoy for Syria. He chose former Secretary General Kofi Annan, who had considerable peacemaking experience.

A six-point plan devised by the international mediator envisaged an end to military operations, the deployment of a UN observer mission, and a transition to internationally assisted intra-Syrian talks (BAN Ki-Moon, 2012). But this simple and, in theory, correct plan failed to get the Security Council's support and was eventually foiled by the Syrian parties themselves. The UN observers were unable to continue their mission amid unending hostilities, provocations from different sides, and artificial constraints on their movements imposed by the Syrian authorities. In June 2012, Kofi Annan resigned after less than six months on the job.

At the same time, the Annan mission prepared the ground for the first consensus-based international document-the Geneva Communique of June 30, 2012-which later served as the basis for UN Security Council Resolution 2254 (2015) that established the legal framework for the Syrian settlement process. Russia-U.S. interaction played the leading role in this sense, despite the differences between 
the two in the Action Group for Syria. At that time, Russia and the United States managed to reach agreement on the main principles of international support for Syrian efforts to emerge from the crisis. These documents formed the foundation of the mandate issued to the Secretary General's subsequent Special Envoys for Syria, former Algerian Foreign Minister Lakhdar Brahimi and Staffan de Mistura, who had previously headed UN missions in Iraq and Afghanistan.

From the start of UN mediation, the political process ran into problems. The earlier approved international legal documents contained guiding principles for the settlement and a roadmap with timeframes for each of its stages lestablishment of a transitional body with executive powers, drafting of a new constitution, and free elections under international supervision). The most important of the factors that ultimately predetermined the negotiating stalemate in Geneva were the following:

- In the documents on the Syrian settlement process, the UN Security Council was identified as the main and sole implementation mechanism and tool for supporting the Special Envoy. In case of a split in its ranks, the political capital of international mediation would be devalued.

- The U.S.-Russia divide was growing in interpreting the provisions of the Geneva Communique and UN Security Council Resolution 2254 related to the meaning of the transitional period and the sequence of steps. Most of the clashes were over the status and powers of the "transitional governing body" and President alAssad's role and position during that period. Until recently, both the U.S. and the opposition urged his resignation as a precondition for direct intra-Syrian talks. There were no feasible grounds for this farfetched interpretation in the foundational documents.

- There was no support from the Syrian parties whose calculations were based on the assumption of military victory. In September 2016, Russian-American interaction was discontinued, which made it more difficult for the international mediator to compel the Syrians to start negotiations. Intervals between rounds of talks grew lengthier, the escalation of violence continued, and political issues were overshadowed by snowballing humanitarian problems. 
- Protracted debates continued on what should come first-the fight against terrorism or agreements on the parameters of the transitional period, that is, the division of power.

- Divides within the political opposition unfolded, there was persistent internal friction and reshuffling as opposition groups vied for leadership, and inability to enlist the support of field commanders, whose divisions reflected the rivalry between Saudi Arabia, Qatar and Turkey, was obvious.

- A sufficiently strong pressure on the Syrian parties was required. While the Syrian army was having success on the battlefield following Russian intervention and the opposition was increasingly inclined to scale back their inflated demands to more moderate ones, Damascus displayed less and less willingness to make concessions and even veered towards tougher political positions.

- The intra-Syrian and international negotiating venues became increasingly fragmented, which reduced the importance of the Geneva format.

It must be noted that the two major diplomats of international stature armed with an international mandate failed to achieve an effective cessation of hostilities, ensure the unimpeded delivery of humanitarian aid, or bring together the Syrian government and the opposition for direct talks, although they did conduct intensive negotiations in different formats and with various combinations of participants. At the same time, it was largely due to their efforts that the sluggish political process in Geneva was kept going and gradually revealed its weaknesses. In early 2017, it became clear that the military situation had to be stabilized, if the sides were to emerge from the protracted political stalemate. Russia focused on cooperation with Turkey, which had by that time expanded its influence over different organizations of Syrian militants and had shown willingness to cooperate with Russia in Syria. The two were later joined by Iran, which also had a stake in de-escalating the military standoff, and thus the Astana negotiating mechanism, or the Astana format, took shape (Astana, now Nur-Sultan, is the capital of Kazakhstan, where the first meetings were held).

This format, in which Staffan de Mistura was involved, had peculiarities and advantages of its own. It was for the first time that 
Syrian government representatives sat down at the negotiating table with commanders of armed opposition units, whom Damascus had lebeled terrorists. Acting in coordination and on parallel tracks, Russia, Turkey, and Iran provided guarantees that the agreements reached by the sides would be implemented. Turkey was responsible for the "cooperative behavior" of the groups under its influence, while Russia sought to obtain the same response from Damascus. Iran in this complicated setting was supposed to restrain the uncontrolled actions by Hezbollah and Shiite militias. An important result of the regular Astana meetings was the agreements on the four deescalation zones, which for the time being made it possible to reduce the severity of military operations and step up efforts to achieve local ceasefires. The opposition attached much importance to confidencebuilding measures (release of prisoners, prisoner exchanges, etc.), lifting the blockade from a number of populated localities, and delivering humanitarian aid to areas in distress.

The agenda of the intra-Syrian talks in Astana was expanding, eliciting a negative response from the U.S. and leading EU countries, which claimed that the Astana format was encroaching on the political field that UN Security Council Resolution 2254 had set aside for the Geneva process and the mediation of the UN Secretary General's Special Envoy. The relationship between these two formats plagued contacts with Western partners for a long time, the latter expressing distrust of Moscow's peacemaking efforts and suspecting it of attempting to "circumvent" some key provisions of the UN documents and devalue the UN role in the context of the Syrian settlement process. In response, Russia repeatedly explained that the Astana talks and the Russian-Turkish-Iranian summits were aimed at finding compromises and helping the Geneva process and that there was no alternative to settling the Syrian crisis on the basis of international law.

At the same time, the new military realities and changes in the alignment of forces between the regime and the opposition called for certain adjustments in the order and sequence of actions to implement the key provisions of UN Security Council Resolution 2254. While cooperating with the UN Special Envoy, the Syrian government refused to discuss the essentials of establishing, to quote the 
Geneva Communique, "a transitional governing body" capable of exercising "full executive powers." Instead, they suggested various options for a broad-based dialogue in Damascus to form a national unity government, all of which were absolutely unacceptable to the opposition.

This gave rise to the idea of starting a substantive intra-Syrian dialogue by discussing a draft new constitution, the adoption of which appears as one of the central points on the roadmap of the political process. Since late 2017, the Special Envoy has focused on forming a Constitutional Committee. This effort was assisted by Russia, Turkey, and Iran, which were holding regular trilateral summits. The Syrian National Dialogue Congress in Sochi (January 2018) made an important contribution to this effort by adopting a key decision to start drafting a new constitution under UN auspices.

Staffan de Mistura's efforts in this regard, which continued until his resignation in December 2018, showed clearly the full extent of distrust between all sides with political influence. It became obvious that finding points of contact between the interests was a tall order. Russia, for its part, sought to create a broad field of accord on a "balanced and inclusive basis" around the "third list" candidates representing civil society and independent experts (Committee members from the government and the opposition were finally introduced). But Western partners were jealous of Russia's leading role in these efforts. At the same time, steps to finalize the Constitutional Committee's composition were complicated by the position of Damascus that regarded the constitutional process as a "purely sovereign affair" of the Syrian people without any foreign interference, thereby effectively disavowing the UN track.

Simultaneously, a situation that was generally favorable for a gradual transition from the military phase to a political process emerged by early 2019. A rough consensus was forming that the Geneva-2 negotiating paradigm based on the "regime platform" vs the "opposition platform" had outlived its usefulness in the new situation and that there was little promise of any further progress on this track (Centralization and Decentralization, 2018). The new military realities are recognized by the U.S. and Russia's European partners, which are no longer insisting on regime change. Instead, they are empha- 
sizing the need for constitutional reform as soon as possible, to be followed by free elections under UN auspices in conformity with UN Security Council Resolution 2254. The main question is how to bring all components of the political process to their common denominator and whether this is possible in principle against the background of the mounting conflict between Russia and the West.

\section{MAIN COMPONENTS OF THE SYRIAN SETTLEMENT PROCESS}

The basic elements, without which Syria's return to peace and national reconciliation appears impossible, include constitutional and government reform, economic reconstruction, urgent humanitarian aid needed by nearly a half of the population, the return of refugees, a reorganization of the army and security services, UN-supervised elections, and much more.

Post-war Syria's government and political system and its constitutional legitimation are among the key issues at the center of the clash of external interests and internal divisions in Syria. A timetable and procedure for drafting a new constitution is a central requirement for the transition to "inclusive and non-sectarian governance," as contained in UN Security Council Resolution 2254. For all the discrepancies related to the sequence of steps in the transitional period, the international community is evolving a more or less common understanding that the starting point should be the launch of a Syrianled constitutional process, as envisaged by the resolution.

Syrian lawyers and political scientists are advocating two approaches: 1) approving a new constitution, or 2) amending the 2012 law now in effect. Damascus is calling into question the very need for a new constitution in the belief that it is able to deal with all these issues on its own without making substantial concessions. The Syrian opposition, which is riven by divisions on many other issues as well, was basically in favor of a new constitution. But many of its realistically minded members have lately agreed to take as a basis the 2012 constitution, provided there are substantial amendments to it (Constitutional Options for Syria, 2017). In effect, this concerns transitioning from a strictly presidential to a presidential-parliamentary form of governance. The administrative system should be decentralized but the state should retain its unitary 
nature, and the constitution will contain the necessary guarantees of the country's territorial integrity. Any type of a federation is regarded as aimed at partitioning Syria and resolutely rejected by both the regime and the majority of the opposition. This is the little they have in common.

The effort to form a Constitutional Committee has run into serious problems and shown that the drafting of amendments to the current constitution will take a long time. The sticking point is the territorial administrative issue that hinges on the Kurdish factor.

During the war, the Kurds, with support from the U.S. that backed them in the fight against ISIS, managed to create a strong military organization and a system of local governance beyond the reach of Damascus in northern and eastern Syria. The uncertainty regarding the continued U.S. military presence in Syria and the unpredictability of their U.S. ally forced the Kurds to choose between confronting a military threat from Turkey and coming to terms with Damascus. The Kurdish leaders are seeking to retain the de facto autonomous status of their cantons, and to prevent the disbandment of Syrian Democratic Forces units that could assume responsibility for security east of the Euphrates.

The Syrian government's position regarding a special administrative status for the Kurds remains essentially unchanged. According to a statement by Minister of State for National Reconciliation Affairs Ali Haidar, no Syrian province can enjoy preferences that would "differentiate it from other provinces or ethnicities" (Reuters, $2018 \mathrm{~b})$. Relevant talks are still in progress on various decentralization formats including decentralization at the level of local communities or the establishment of some asymmetrical territorial administrative system. Law No. 107 on local governments, which is now in effect and acceptable to the opposition, might become a workable basis for discussing the entire gamut of these issues.

Economic revival is another vital aspect of the Syrian settlement process. Of all the conflicts in the region, Syria has suffered the greatest losses in terms of material destruction, casualties, and decline in the quality of human capital. During the war, its GDP has contracted by more than 50 percent, whereas it should have grown by 40 percent under the pre-war economic plan. The budget deficit 
has increased by more than 1,500 percent. The UN estimates the total damage caused by the hostilities at $\$ 250$ billion, whereas the Syrian government has suggested that about $\$ 400$ billion is needed for rebuilding infrastructure alone. According to expert calculations, humanitarian aid requirements are also adding up to the impressive sum of $\$ 20$ billion. More than 70 percent of families are suffering from malnutrition, 80 percent of Syrians have fallen below the poverty line, while life expectancy has been reduced by 20 years.

Under these circumstances, Syria is unable to recover without outside aid. Financial losses and destruction have reached a scale that makes economic reconstruction an insurmountable problem for Syria, or for any other state or even group of states. Conscious of the importance of the economic and humanitarian components of the settlement, Russia has proposed that the U.S., the EU, and other potential donors pool efforts to mobilize resources for economic recovery and the return of refugees.

But a coordinated international policy, even at the UN level, is still lacking, despite the realization that the material damage caused to Syria and its humanitarian plight are unprecedented since the end of the Second World War. The U.S. and EU countries are refusing to finance reconstruction of government-controlled areas in Syria lor more than 70 percent of the most densely populated territory with its infrastructure almost entirely in tatters). Their condition for giving aid is that Syria be transformed as part of a "credible" political process. What is primarily meant is the drafting and approval of a new Syrian constitution to be followed by UN-supervised "free and fair" elections.

The West hopes to use these political terms as a tool to pressure Damascus and its allies. Apart from political considerations, the refusal to cooperate directly with the Syrian government is justified by citing the need to implement administrative reforms and modify property and investment laws. Western experts believe that directing international economic aid through official channels to the country's militarized economy would inevitably strengthen corrupt businesses and local militias in cahoots with the regime (Heydeman, 2017). Still worse, the Syrian leaders, for their part, are also politicizing economic reconstruction issues by declaring that they are not prepared to receive aid from "accomplices of terrorism." Their hope is that a 
number of EU countries might change their approaches if Damascus displays sufficient firmness. This can be seen in President al-Assad's statements to the effect that "the Syrians are able to restore the country on their own" and that "they will not need the West's aid for that" (RBC, 2018). The European countries have indeed split into resolute opponents of cooperation with a "regime that is unamenable to reform" and a conciliatory group that hopes for rapid stabilization or their companies' participation in lucrative projects (Asseburg and Oweis, 2017). It is clear today that developing a coordinated economic rehabilitation project for Syria is a mission for the entire international community, given that the conflict's grave political and humanitarian aftermath has extended far beyond the Middle East region.

The refugee problem is inseparably linked with Syria's reconstruction. Syrian refugees make up no less than one-third of the world's displaced persons. According to UN statistics, nearly a half of Syria's pre-war population has been forced to leave their places of residence 15.6 million refugees and 6.6 million internally displaced persons). The biggest number of refugees ( 3.5 million) have fled to Turkey. There are also one million refugees in Lebanon and 650,000 in Jordan (Syria Emergency, 2018). This problem is dragging down neighboring economies and creating serious political and social challenges. In Lebanon, where Syrians make up 20 percent of the population, the refugees have become, to quote Prime Minister Saad Hariri, a "time bomb." Real GDP growth rates have been slowing in Jordan over the last three years and per capita income has not budged since 2012 (Nemeh, 2017).

The Syrian government should have a stake in creating a favorable civic environment for a number of obvious reasons, including the need to restore trust, engage the average business owner, normalize relations with the West, and, last but not least, hold elections (the presidential elections are scheduled for 2021) that would be recognized as legitimate. Russia's appeals and initiatives were instrumental in inducing refugees to return, starting in mid-2018, mainly from Lebanon and Jordan, as well as from Turkey to areas not controlled by the Syrian government. But there are a number of circumstances obstructing a full-scale return of refugees, most importantly the position of the U.S. and the EU, which are of the 
opinion that the internal conditions for a voluntary and safe return are yet to be created. The same view is held by the UN Refugee Agency (UNHCR). According to a Carnegie Endowment study, despite the fact that the majority of refugees are willing to return home, it is unlikely that they will be able to do so in the short term, even if military operations come to an end (Yahya, Kassir and Hariri, 2018).

To create an internal environment incentivizing the beginning of a large-scale repatriation process, a number of preconditions have to be met, as demonstrated by international practice in other conflict zones. These include security, legal guarantees of property rights, the possibility to return to former residences, amnesty for draft evasion, the availability of jobs and social services, and restoration of the healthcare and education systems. This means that much depends on the Syrian government itself, on whether it is able to cope with these major challenges, and if it has the necessary political will.

In the meantime, opposition representatives inclined to come to terms with the government, as well as Western sources, note how inconsistent and contradictory Damascus has been in its efforts related to this sphere of post-conflict reconstruction. Particularly puzzling was the adoption of Law No. 10 of April 2, 2018 (Reuters, 2018a), which enables the Syrian government to confiscate real estate and use it for urban redevelopment without paying compensation to the owners. Syrian citizens regardless of their actual residence are ordered to submit ownership documentation within 30 days, which is basically unrealistic for refugees. It is widely believed that the government-backed law targets the regime's opponents and is intended to resettle loyalists in new development areas in major cities. Although reassuring explanations were offered later and the enforcement of the law was modified, the fact that this law was approved at all did nothing to help restore trust and had negative repercussions.

Implementing other repatriation terms will require real socioeconomic reforms, reorganization of numerous security services and the army, reintegration of combatants into peaceful life, an overhaul of the legal system, and, most importantly, a change in mentality from "winner takes all" to true national reconciliation in which there are "no winners, no losers." 


\section{POST-WAR SYRIA'S PROSPECTS: RUSSIAN INTERESTS}

During the war years, Russia achieved many of the strategic aims it set for the operation in Syria (including through its military diplomacy):

- curtailed efforts of regime change in Syria;

- prevented the coming to power of radical Islamists, the region's subsequent destabilization, and the spill-over of militant Islamism to Russian territory;

- crushed ISIS as a terrorist territorial entity and its military infrastructure. Although the intention to create a joint antiterrorist coalition proposed by Russia failed, Russia and the U.S. fought against ISIS on parallel tracks, albeit separately;

- restored government control over more than two-thirds of Syrian territory;

- consolidated Russia's positions in the Eastern Mediterranean, which has historic significance for the Russian Navy;

- confirmed Russia's status as a world power.

All this raises the question: What's next? What succession of military efforts and diplomatic steps should ensue?

The military-political situation on the ground limits Damascus' opportunities to independently direct further advances of its armed forces. Apart from military and humanitarian problems, liberating Idlib as well as northern and eastern areas by force is contingent on reaching political understanding and some intricate compromises in a broader format rather than between Russia, Turkey, and Iran alone. At this stage, Russia must deploy artful diplomatic maneuvering in order to preserve mutual understanding with its Astana partners without alienating Israel. It will be a difficult challenge to address the legitimate security concerns of Iran and Israel and prevent a clash between them.

We must not discount the possibility of establishing working relations on the post-conflict settlement in Syria with the U.S. outside the channels of military communication that, as both sides admit, are functioning successfully. Contrary to Trump's statements, the U.S. is not going to phase out its military presence in Syria. It does not matter in this case whether the force is reduced and, if so, to what extent, because as the Americans have repeatedly shown, their special forces in eastern Syria will remain under the permanent 
protection of U.S. air power. Keeping a limited contingent in Syria, according to the majority in the U.S. military-political establishment, is seen as a chance to "waive the flag" at multilateral talks on Syria, while keeping an eye on Iran's military communication lines between Iraq, Jordan, and Lebanon.

A new alignment of forces in the conflict symbolizes a certain completion of its military phase and, as logic suggests, creates prerequisites for progress on the political track. The question is what is to be understood by a political solution? Is it a long-term settlement or a mere pretence of one based on superficial changes? A picture of victory is clearly discernible already. This refers in particular to the triumphant mood in Damascus. Allegedly, a military solution has been achieved despite everyone's claims that a military solution was impossible. This means that the future course of the political process should be determined by the winners. Syria's tactics, as outlined by President Bashar al-Assad, consists of working towards reconciliation, but if proved ineffective, using military force to liberate the rest of the country, including from the "U.S. occupation" (Gazdiev, 2018).

This approach is fraught with numerous dangers. As we know from the history of other civil wars, a full victory achieved by one of the sides does not guarantee that peace will return, if the original problems that caused the conflict remain unresolved and the winners continue to face a hostile external environment.

The West has, in effect, recognized that Russia plays a "key role." But it also has been erecting obstacles seeking to make Moscow exert pressure on Damascus, which has always been a much needed, yet difficult, partner for Russia. In this way, responsibility for the final result is being placed on Damascus and its allies. If the U.S. and Europe manage to find points of contact with Russia to develop a common vision for post-war Syria, they will be ready to work together; if not, then any of the current players will be able to act as a spoiler by destabilizing the situation.

It is in Russia's interests to steer the process towards a durable settlement, proceeding from the assumption that the post-war arrangement in Syria cannot be the same as before the war. A new military reality must be consolidated, with the power structure resting on a truly inclusive basis and representing a wide spectrum of national 
patriotic forces, including the political interests of the Sunni majority. Otherwise, the fruits of military success could be lost over time.

Of considerable importance for reaching a long-term settlement is the effort to restore Syria's relations with both-its immediate neighbors (there has been some positive movement in this regard) and the outside world. It is in Russia's interests to work for a settlement that is the result of international consensus, including the international community's recognition of a reformed Syrian regime's legitimacy and Russia's long-term military presence in Syria. If Russia outlines its strategic interests in Syria in a more open and clear manner and signals its readiness for multilateral compromise, it has ample opportunities and military-political influence to secure its interests by non-confrontational means. After so many sacrifices and humanitarian disasters, the ice of mutual antagonism and hatred can only be broken by long-term, patient and, most importantly, uninterrupted multilateral efforts in different combinations.

\section{References}

Al Bunni, A, n.d. A Critical Reading of the New Syrian Constitution (in Arabic).

Asseburg, M. and Oweis, K.Y, 2017. Syria's Reconstruction Scramble. German Institute for International and Security Affairs, December. Available from: https://www.swp-berlin.org/en/publication/syrias-reconstruction-scramble/ BAN Ki-Moon, 2012. Letter of UN Secretary General BAN Ki-Moon to Ms. Susan Rise, President of the Security Council. 18 April, New York, p.1.

Centralization and Decentralization, 2018. Centralization and Decentralization in Syria: Concepts and Practices. Fourth Annual Book. Omran Center for Strategic Studies, 15 November, p.13.

Constitutional Options for Syria, 2017. United Nations Economic and Social Commission for Western Asia, National Agenda for the Future of Syria (NAFS) Programme. Available at: http://nafsprogramme.info/library/constitutionaloptions-syria.html

Gazdiev, M., 2018. "Libo u nas est' strana, libo ee net": Asad o budushchem Sirii i podderzhke so storony Rossii ["Either We Have a Country, Or We Do Not": Assad on the Future of Syria and Russia's Assistance], RT, 31 May. Available at: https://russian.rt.com/world/article/518376-intevyu-bashar-asad

Heydeman, S., 2017. Rules for Reconstruction in Syria. Brookings, 24 August. Available from: https://www.brookings.edu/blog/markaz/2017/08/24/rulesfor-reconstruction-in-syria/ 
Iranians Respond, 2018. Iranians respond to the regime: "Leave Syria alone!" Al Jazeera, 2 May. Available at: https://www.aljazeera.com/indepth/opinion/ iranians-respond-regime-leave-syria-180501081025309.html

Nemeh, B., 2017. Jordan's Burden. Carnegie Middle East Center, 21 March. Available at: http://carnegie-mec.org/diwan/68330

RBC, 2018. Asad otkazalsia ot pomoshchi Zapada v vosstanovlenii Sirii' [Assad Refuses Western Assistance in Syria's Reconstruction]. RBC, 24 June. Available at: https://www.rbc.ru/politics/24/06/2018/5b2f7e079a7947 893e238e9d?from=main_rigt

Reuters, 2018a. Assad's property law hits hope of return for Syrians in Germany. Reuters, 14 June. Available from: https://www.reuters.com/ article/us-mideast-crisis-syria-germany-insight/assads-property-lawhits-hope-of-return-for-syrians-in-germany-idUSKBN1JA1V1

Reuters, 2018b. Syrian Minister: Syria's Kurdish-Led Northeast to be Treated Like Rest of Country. Reuters, 4 September. Available at: https://www.reuters. com/article/us-mideast-crisis-syria-kurds/syrias-kurdish-led-northeastto-be-treated-like-rest-of-country-syrian-minister-idUSKCN1LK2FN

Reuters, 2019. U.N. Agency Calls for More Access in Syria to Help Refugees Return. Reuters, 9 March. Available at: https://www.reuters.com/article/ us-mideast-crisis-refugees-grandi/u-n-agency-calls-for-more-access-insyria-to-help-refugees-return-idUSKBN1QQ0JM

Syria Emergency, 2018. The UN Refugee Agency, 19 April. Available at: http:// www.unhcr.org/syria-emergency.html

The Iranian-Saudi Hegemonic Rivalry, 2017. Belfer Center, 25 October. Available at: http://www.belfercenter.org/publication/iranian-saudihegemonic-rivalry

Yahya, M., Kassir, J. and Hariri, K., 2018. Unheard Voices: What Syrian Refugees Need to Return Home. Carnegie Middle East Center, 16 April. Available at: https://carnegie-mec.org/2018/04/16/refugee-attitudestoward-return-to-syria-pub-76061

Valdai, 2014. Zasedanie Mezhdunarodnogo Diskussionnogo Kluba "Valdai". Valdai International Forum Session, 24 October. Available at: http://kremlin. ru/events/president/news/46860

Wieland, C., 2012. Syria-A Decade of Lost Chances. Repressions and Revolution from Damascus Spring to Arab Spring. The Wall Street Journal, 31 January, p. 29. 